This item was submitted to Loughborough's Research Repository by the author.

Items in Figshare are protected by copyright, with all rights reserved, unless otherwise indicated.

\title{
Closing seminars and lectures: The work that lecturers and students do
}

PLEASE CITE THE PUBLISHED VERSION

https://doi.org/10.1177/1461445617701992

PUBLISHER

() The Authors. Published by Sage.

\section{VERSION}

AM (Accepted Manuscript)

\section{PUBLISHER STATEMENT}

This work is made available according to the conditions of the Creative Commons Attribution-NonCommercialNoDerivatives 4.0 International (CC BY-NC-ND 4.0) licence. Full details of this licence are available at: https://creativecommons.org/licenses/by-nc-nd/4.0/

\section{LICENCE}

CC BY-NC-ND 4.0

\section{REPOSITORY RECORD}

Tyagunova, Tanya, and Christian Greiffenhagen. 2019. "Closing Seminars and Lectures: The Work That Lecturers and Students Do". figshare. https://hdl.handle.net/2134/23189. 


\title{
Closing Seminars and Lectures:
}

\section{The work that lecturers and students do}

\author{
Forthcoming in DISCOURSE STUDIES
}

Authors: Tanya Tyagunova, Martin Luther University Halle-Wittenberg \& University of Kassel, Germany;

Christian Greiffenhagen, The Chinese University of Hong Kong, China \& Loughborough University, England

Version: 2, 19 October 2016

Corresponding author: Tanya Tyagunova

Address: Hegelstr. 10, 06114 Halle (Saale), Germany

Emails: tatyana.tyagunova@zsb.uni-halle.de

c.greiffenhagen@cuhk.edu.hk

Short title: Closing Seminars and Lectures

Size of the paper: 9207 words 


\begin{abstract}
Based on an analysis of naturally occurring interactions between lecturers and students, this article investigates how university lectures and seminars are brought to a close through the collaborative work of lecturers and students. The analysis focuses on: firstly, the resources that lecturers and students have to accomplish this (which do not just include speech, but also embodied conduct, as well as references to clock time and lesson phases); secondly, the active role that students play, who may engage in closing activities in ways that attempt to preserve the classroom order (e.g., by packing up silently while continuing to demonstrably listen) or in ways that are disruptive of it (e.g., by packing up noisily); thirdly, the occasional subversive role that students may adopt, who may attempt to initiate closings in order to cut the lecture or seminar short (e.g., by suggesting to the lecturer that he or she is going over time or by engaging in 'premature’ closing activities).
\end{abstract}

\title{
Keywords:
}

closings; classroom interaction; classroom management; embodiment; time; lectures; seminars; conversation analysis; ethnomethodology 


\section{Introduction}

This paper investigates how lecturers and students collaboratively accomplish the closing of university lectures or seminars. Like many other institutional encounters, lectures and seminars are scheduled affairs, with pre-defined start and end times. Nevertheless, lectures and seminars can end both before and after their 'official' scheduled end time. Consequently, lecturers and students have to work to bring a seminar to a close in an orderly fashion.

A number of studies have investigated the accomplishment of the beginning, or opening, of (school) classroom lessons. These studies have shown how the teacher's talk at the beginning of a lesson is understood categorically as 'teacher' talk (Payne, 1976; Francis and Hester, 2004: 115-121), how reference to the clock time in a teacher's talk is used as a resource for the control of students' activities (Payne, 1979; Payne and Hustler, 1980), or how the beginning of a lesson is constituted through producing a two-party structure (Payne, 1979; Macbeth, 1987, 1992). However, so far there is a paucity of research that has looked at the closing of lessons and seminars, although there has been research on the closing of other activities, such as ordinary conversations (Schegloff and Sacks, 1973; LeBaron and Jones, 2002), news interviews (Clayman and Heritage, 2002, Chapter 3), or medical consultations (Heath, 1985; Robinson, 2001; West, 2006). This paper contributes to such work on closings by providing a detailed analysis of the different ways in which lecturers, and students, produce a closing of a lesson or a seminar.

Classrooms have long been regarded as places where both knowledge and rights of access to particular types of activities are asymmetrically distributed. Accordingly, in many studies, educational practices are often conceptualized in terms of the teacher's power and authority. Literature in this field is rich in related metaphors. For example, Giddens (1984: 136) sees the school as 'a power container', Bourdieu and Passeron (1990 [1977]: 11) define pedagogic 
action as 'a power of symbolic violence', while Jackson (1968: 31) characterises the teacher as "the students' first 'Boss"”. In these and other studies in the field of sociology of education power and authority have been conceptualized as a mechanism of reproduction of unequal social and cultural relations through the educational system (e.g., Young, 1971; Bernstein, 1975; Apple, 1995; Luke, 1995-1996). The social organization of classrooms has been analyzed in terms of institutional rules and roles, status and expectations, teachers' professional competence and classroom styles (e.g., Hargreaves et al., 1975; McNeil, 1982; Koutrouba et al., 2012). As a result, such analyses in formal-analytic terms often "lose and even misread” (Macbeth, 2003: 254) the phenomena under consideration.

An alternative approach to the study of classroom order and classroom management has been offered through work influenced by ethnography of communication, ethnomethodology and conversation analysis (e.g., McHoul, 1978; Mehan, 1979; Cooper, 1982; Macbeth, 1987, 1992; Margutti, 2011; Margutti and Drew, 2014). These studies have taken the perspective that the organization of classroom order is to be found in the organization of the classroom talk and details of the interactional work. Within this research perspective, the order in the classroom is understood as an observable, material phenomenon of everyday practices that are methodically constituted and manifested in the local scenes of the everyday classroom life. Rather than constructing analyses through theories or models, these investigations initiated a rigorously naturalistic program for studying the educational phenomena, which was based on the close analysis of actually occurring practical actions.

However, the majority of these studies were undertaken from the perspective of the teacher. They focused the analysis on the unequal distribution of communicative rights and responsibilities and teacher control thereby conceiving of students as constrained on their opportunities to have access to speaking turns and other forms of participation in the class (Sinclair and Coulthard, 1975; McHoul, 1978; Payne and Hustler, 1980). Paradigmatic here is 
the research into a three-part model, the Initiation-Response-Feedback/Evaluation [IRF/IRE] sequence, as the most dominant structure of classroom interaction, which has been commonly seen as a way of the teacher dominating classroom discourse. For example, McHoul (1978) remarks that "[o]nly teachers can direct speakership in any creative way" (188), while "student participation rights being limited to the choice between continuing or selecting the teacher as next speaker” (211).

By contrast, some studies have shifted away from a teacher-centred analytical perspective to a more complex view of the organization of classroom lessons, emphasizing the essentially cooperative and negotiated nature of the constitution of the classroom order (e.g., Macbeth, 1990, 1991; Francis and Hester, 2004: 121-128; Waring, 2011; Park, 2012; Koole and Elbers, 2014). These studies have shown that although the teacher seems to possess 'all the power' (Paoletti and Fele, 2004: 70), he is reliant on students' active collaboration in the construction of the classroom order.

In other words, recent studies have explicitly focused on how the classroom activities are regulated not only by the teacher, but also by the students. These investigations have shown that resources available to the teacher as the 'legitimated' organizer and controller of classroom activities can also be actively used by students. Firstly, they have demonstrated that students can manage and influence classroom interaction even within the IRE structure (Candela, 1999; Jacknick, 2009; Garton, 2012; Kääntä, 2014). For example, Candela (1999) has shown how students can change the situational power asymmetry by using such strategies as refusing to participate in the discussion, alternative ways of answering the teacher questions, evaluating teacher's and peers assertions, or initiating a new topic for discussion. Secondly, they have made evident that not only talk, but also time and space are resources available to, and used by, students to establish and influence the classroom order (e.g., Manke, 1997; Breidenstein, 2006; Hecht, 2013). For example, Manke (1997: 108-110) 
describes students deliberately misunderstanding what the teacher wanted them to do, 'wiggling' or otherwise pushing the limits of 'sitting in a seat', as well as tuning out or withdrawing attention.

This paper aims to contribute to this line of research by showing how not only the lecturer, but also the students contribute to the closing of sessions. While most studies so far have focused on the field of school education, ours looks at university lectures and seminars, the field where relatively little work has yet been done.

\section{Data and Method}

This study is based on audio- and video-recordings, as well as ethnographic observations, of naturally occurring interactions between lecturers and students from three sources: firstly, university seminars recorded in Germany and Belarus in 2011/2012 (49 seminars with five different lecturers in Belarus, 37 seminars with four different lecturers in Germany); secondly, graduate lectures in mathematics recorded in England in 2004 (20 lectures with three different lecturers); thirdly, undergraduate lectures in social science recorded in England in 2014 (ten lectures from one lecturer).

The fragments presented below were translated into English (Fragments 1, 2, 3, 6, 9.1, 9.2, 10, 11, 12, 13.1 and 13.2 are based on German corpus data, Fragments 5, 14 and 15 draw on Belarussian corpus data). The original Transcripts may be requested from the authors at any time.

We approached these from the perspective of ethnomethodology (Garfinkel, 1967, 2002) and conversation analysis (Sacks, 1992; Schegloff, 2007). Studies in this tradition have investigated a variety of taken-for-granted aspects of social interaction. Those aspects could be said to be the 'dark matter' of social interaction (Schegloff, 1996: 211; Lindwall and 
Lymer, 2008) and although in a certain sense 'uninteresting', especially to participants, they are nevertheless essential to accomplishing practical affairs. The challenge of such studies is not to uncover hidden phenomena that only become observable through new methodological tools or theoretical lenses, but to take interest in public organizations, and pay attention to the way in which unnoticed doings contribute to getting things done.

\section{Lecturers' work}

We will start our analysis of the accomplishment of closings by focussing on the work of the lecturer who has the authority to organize and control classroom activities, including the closing of these (see Payne, 1979: 269; Macbeth, 1987: 174; Clayman, 1989: 687). Using Turner's terminology (1972: 395), the lecturer is an 'authorized closer' of seminars or lectures. Thus, it is the lecturer who usually initiates the closing which can be done 'on time', or, in the many cases, a few minutes before the end of the session (in contrast to schools, there are typically no bells that ring at the end of a session in universities; but see Macbeth, 1987: 139, Macbeth, 1992: 137 for schools).

\section{Announcement of closings}

Many university lectures and seminars are brought to a close in a relatively straightforward manner, in that the lecturer announces, towards the scheduled end time, that the session is over. Such announcements are subsequently followed either by some audible acknowledgement of students (e.g., clapping or knocking on the table - a common practice in Germany) or simply by students packing up and starting to leave. For example, in Fragment 1 , the lecturer ends the seminar by thanking the students (lines 1-2), which prompts students to start to pack up.

\section{Fragment 1}




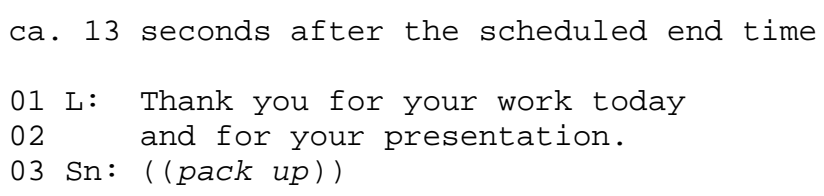

Moving into closing typically does not happen suddenly, but is usually foreshadowed by the lecturer through 'formal markers' (Turner, 1972: 369; Greiffenhagen, 2008: 49), such as “Okay”, "Right”, “Alright”, "Yes”, and the like. Towards the end of the seminar or the lesson, such 'formal markers' could be said to work as a 'pre-closing' (Schegloff and Sacks, 1973: 303; see also Robinson, 2001: 642). Fragment 2 is a typical example of this:

\section{Fragment 2}

ca. 3 minutes before the scheduled end time

$\longrightarrow 01 \mathrm{~L}:$ Alright. Okay. Then (.) thank you (.)

02 for the nice presentation once again (inaudible)

03 And if there aren't any questions

04 Then (.) you are allowed to go.

05 Then I wish you nice (inaudible) celebration

06 and see you next week.

$07 \mathrm{Sn}$ : ((knock on their tables $))$

In line 1, the lecturer by uttering “Alright. Okay.” marks the end of the giving feedback on the students' presentation (lines 2-3) and immediately afterwards announces that the students "are allowed to go" (line 4), to which the students respond by knocking (line 7).

Note that closings themselves often consist of more than one utterance, but that students often do not wait until the lecturer has finished speaking before they start to pack up. Thus in the following fragment, the students knock on the table and start to pack up following the lecturer's utterance “That was it for today” (line 4), thereby overlapping with the lecturer's final utterances (lines 5-8). 


\section{Fragment 3}

ca. 12 minutes before the scheduled end time

\section{$(2.0)$}

2 L: Alright. Yes.

$(2.0)$

That was it for today. (.)

Then, I would say

thank you (inaudible)

it worked really well

despite the difficulties

((Sn knock
on their tables,
stand up,
pack up $))$

stand up,

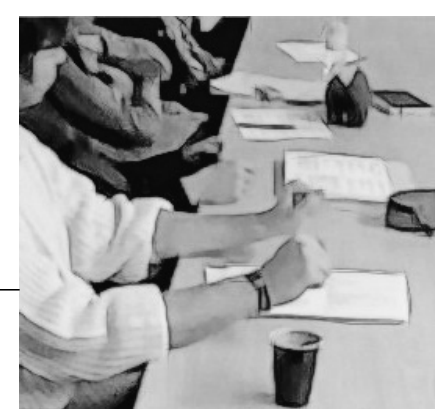

Looking at the interaction between lecturer and students during closings, it is noteworthy that the lecturer's closing utterances, such as "see you next week" or "thank-you" do not require students' verbal response. Similar to lecturers' greetings (cf. Francis and Hester, 2004: 117118), which do not function as a greeting in everyday interaction (which asks for a returngreeting), but more as an instruction that the lesson has started, terminal 'thank-yous' serve to instruct that the seminar is over and do not ask for a verbal response.

\section{The timing and placement of closings}

When are lectures and seminars brought to a close? We have already seen that closing don't have to be right on time. There is rather a 'leeway' for closing. In fact, as Fragments 2 and 3 illustrate, the lecturer usually starts moving into closing some minutes before the scheduled end time and students also expect this (as we will show below).

For the lecturer, bringing a seminar or a lecture to a close is a delicate matter. One of the tasks of a lecturer is to fit whatever he or she wants to accomplish into the available time, i.e., to avoid both to 'run out of time' as well as having 'time to fill' (cf. Hustler and Payne, 1982: 55). In accomplishing this task, lecturers are oriented to the scheduled and phased nature of lessons and seminars, as well as students’ knowledge of this (cf. Payne, 1979; Payne and Hustler, 1980; Hustler and Payne, 1982).

Both lecturer and students are oriented to the passing of time by frequently checking the 
clock. As Harold Garfinkel has put it, lectures are conducted "under the watchful eye of the clock” (Douglas Macbeth, personal communication). All parties are monitoring the clock and are watching its approach to the end of the session, which may prompt various actions.

A simple example of this occurs in the next fragment. Towards the scheduled end time of a lecture, the lecturer has just finished proving one direction of an equivalence proof (cf. Greiffenhagen, 2014). He now has to decide whether proving the other direction will fit into the remaining time.

\section{Fragment 4}

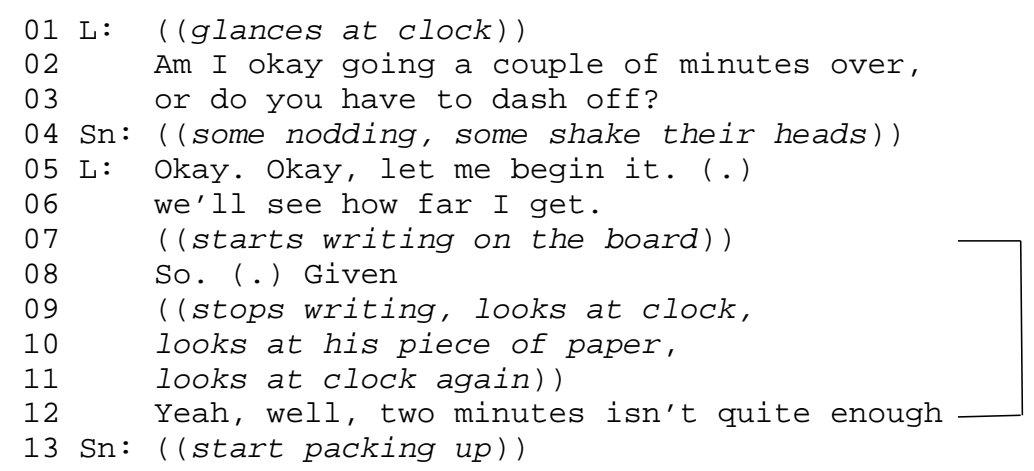

In this instance, the lecturer, after glancing at the clock (line 2), indicates to students that the next part will in fact not fit into the remaining time, but that he would have to go "a couple of minutes over”. He formulates this seemingly as a request for permission to in fact go over the time (to which students may respond in both positive and negative ways). However, he does not really react to students' responses and instead quickly starts writing on the board. After writing for 18 seconds, the lecturer first glances at his piece of paper (which contains the proof that he wants to write on the board), then again at the clock, and visibly 'recognizes' that finishing the proof would require more time than he 'has'. His announcement, "two minutes isn’t quite enough” is heard by students as a closing and they start to pack up.

The lecturer is here faced with an interesting tension: on the one hand, the current proof is 'incomplete' (only one direction has been shown on the board) and it is unsatisfactory to 
finish the lecture at this point (a bit like finishing a social science lecture after a long "On the one hand ...”). On the other hand, the lecture time is almost over and so finishing the proof would mean that the lecture time has to be extended.

We would argue that this also points to a tension between the perspectives of the lecturer and the students. In Fragment 4, the lecturer is obviously concerned with the subject matter (content) and from that perspective, it would make sense to go "a couple of minutes over”. In contrast, students are often (to the complaint of many lectures) more concerned with clock time (partly because they, in contrast to the lecturer, may well have a lecture or a seminar following this one), and therefore want to avoid going beyond the scheduled end time.

While university lectures are typically driven by 'content' (these days often pre-determined by the number of slides the lecturer wants to 'get through'), university seminars typically have re-occurring phases, ${ }^{1}$ such as: lecturer's introduction, first student presentation, feedback, second student presentation, feedback. If the lecturer has finished a particular 'part' or 'phase' towards the scheduled end of the session, he or she is thus often faced with the problem whether there is 'enough' time for the following task or phase. For example, in the following, the lecturer is faced with the problem of whether the next task will fit into the remaining time:

\section{Fragment 5}

ca. 5 minutes before the scheduled end time

$01 \mathrm{~L}:$ okay. That is clear, isn't it?

$02 \mathrm{Sn}$ : ((nodding in agreement))

$03 \mathrm{~L}:$ How much time is left?

$04 \mathrm{~S}:$ Five minutes.

$\odot 5 \mathrm{~L}$ : So, we don't have time for a little role play.

$06 \mathrm{Sn}:$ ( (start packing up))

$07 \mathrm{~L}$ : Next time we will discuss (inaudible)

08 Sn: ( (continue to pack up))

After the lecturer has finished her explanations of the current seminar topic, she checks whether there are any questions (lines 1-2). She then asks students how much time remains 
until the scheduled end time of the session (lines 3-4). It turns out that there are five minutes left and the lecturer quickly decides that this is not enough time for the next task (line 5). This formulation is heard by students as an announcement of moving into closing. Although there is not an explicit announcement of the end of the session, the students start to pack up immediately after her statement in line 5 and the session is finished (on time) after the discussion of some organizational questions.

The tension between the (lecturer's) orientation to the accomplishment of the next seminar phase and the (students') orientation to the clock time can be clearly seen in the following example (Fragment 6). Here, the lecturer not only indicates the next proposed phase (feedback to the presenting students group), but also reprimands the students starting to pack up before this phase is accomplished:

\section{Fragment 6}

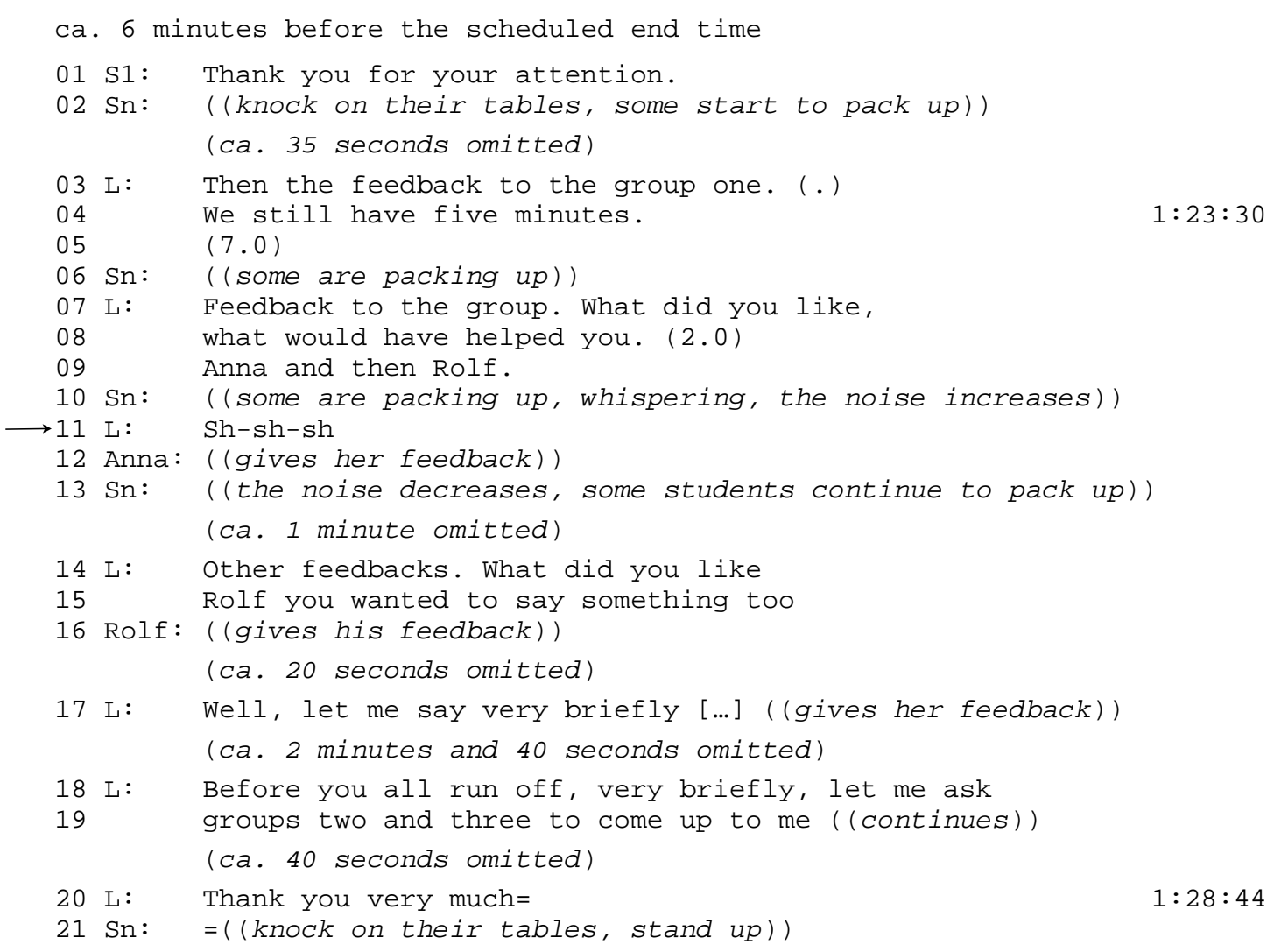


When the presenting student thanks the audience for the attention, some students start to pack up (line 2). The lecturer asks the class to give feedback, i.e., move on to the next - and final phase of the seminar (line 3). The lecturer’s “We still have five minutes” (line 4) can be heard as a reaction to students' packing up. However, some students continue to pack up (lines 6 and 10) and sound increases. The lecturer reprimands the students by saying "Sh-sh-sh" (lines 10-11). This is a situation in which the lecturer's orientation to the accomplishment of the next phase is in a sense contested by students' closing activities.

The fact that students' closing activities become audible and visible can, on occasion, be explicitly addressed by the lecturer. For example, the lecturer can try to prevent or stop students to pack up prior her or his closing turn (cf. Payne, 1979: 269). An illustration of this can be found in the following:

\section{Fragment 7}

ca. 1 minute and 28 seconds before the scheduled end time

$01 \mathrm{~L}$ : But there is no equivalent for adult sexual offenders.

02 The nearest you get, we talked about anti social

03 personality disorder, last week, but we know that

04 anti social personality disorder is not just about being rapists,

05 that can be about all sorts of different types of offending.

06 ((quickly glances at her watch))

07 (8.0) ((looks at the notebook screen,

08 flips through the PowerPoint slides))

$\longrightarrow 09$ Okay.

10 (3.0) ((continues to flip through slides))

$11 \quad I^{\prime} m$ just trying to, just hold on one second.

$12 \quad(2.0)$

13 ((increasing noise in the audience))

14 ((looks up from computer towards students))

$\longrightarrow 15$ This isn't an invitation to start packing, we're nearly there.

In this fragment, the lecturer's “okay” in line 8, which occurs towards the scheduled end of the lecture (which is further marked by the lecturer glancing at the watch), is heard by students as a 'formal marker' that the lecturer has finished with the content of the lecture and thus may have initiated a closing. However, in this instance the lecturer states that she has not yet finished and tells students that her "okay" was not "an invitation to start packing” (line 
15). She thereby explicitly reasserts her right, as a lecturer, to close the lecture (and that students should not engage in closing behaviour prior to her announcement).

This nicely points towards an interesting phenomenon that anyone who has lectured is aware of: the volatility of the final minutes prior to the scheduled end of a lecture, when students are, in a sense, 'waiting' for markers that the lecturer has finished with the content for the lecture and has initiated a closing. In the following fragment, the lecturer can be seen doing work of 'preventing' students' initiating closing activities before her announcement of the end of a lecture. She is doing it by explicit formulating the 'appropriate' way of students' behaviour towards the end of a lecture:

\section{Fragment 8}

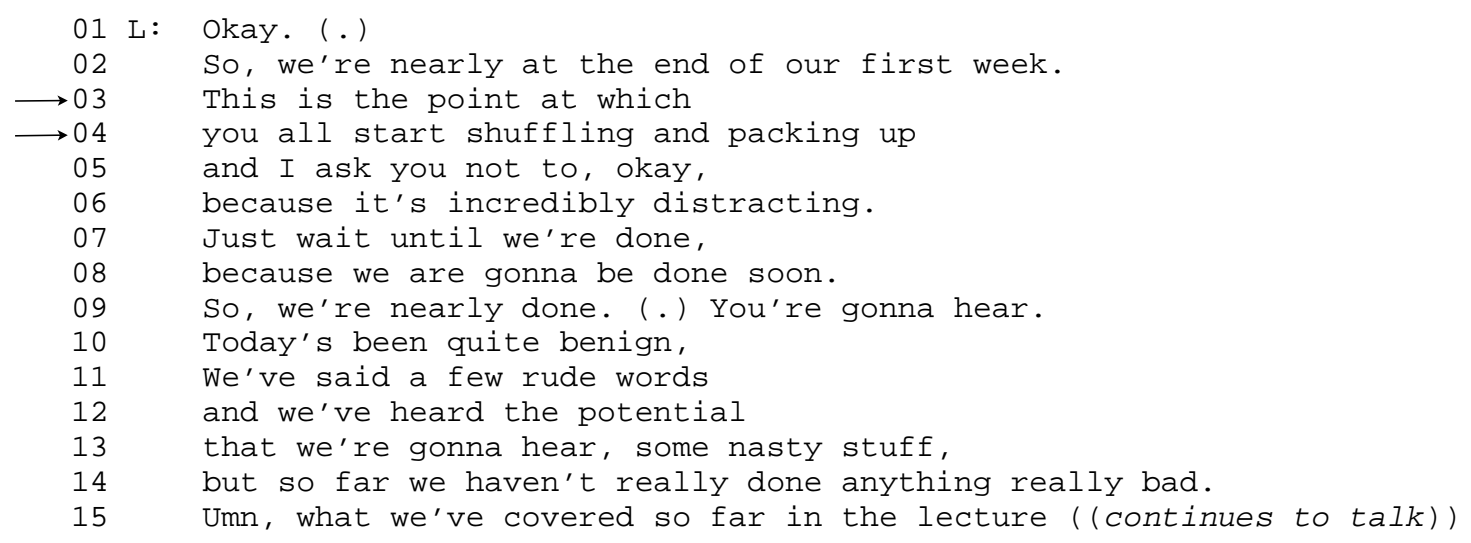

The lecturer indicates that students' packing up prior to her closing is seen by her as disturbing (lines 3-6). However, this is not always the case. As we will see in the following sections, students may engage in packing up prior to the lecturer moving into closings.

\section{Students' work}

Just like classroom lessons, university seminars and lectures are characterized by a certain asymmetry in the sense that the right of closing is the entitlement of the lecturer. However, as we have already seen, students are by no means passive in relation to closing the seminar, but 
can in various ways actively contribute to the closing of lectures. The perhaps most common practice is for students to simply start packing up. Although sometimes students start to do this only after the lecturer has formally closed the session (see Fragments 1 and 2), very often students start to do initiate such 'closing work' in parallel with the lecturers closing remarks (see Fragment 3), or even prior to this (see Fragment 6).

\section{‘Gearing up' to leave}

In other words, students often start to 'gear up' (Jefferson, 1984; Ivarsson and Greiffenhagen, 2015) to leave, e.g., by packing up their pens and papers into their bags or by putting on their scarfs, but not yet getting up and leaving the room. In many cases, this is done silently, towards the end of clock time, and in a cooperative manner. Fragment 9 is a typical instance of this.

\section{Fragment 9.1}

ca. 5 minutes before the scheduled end time

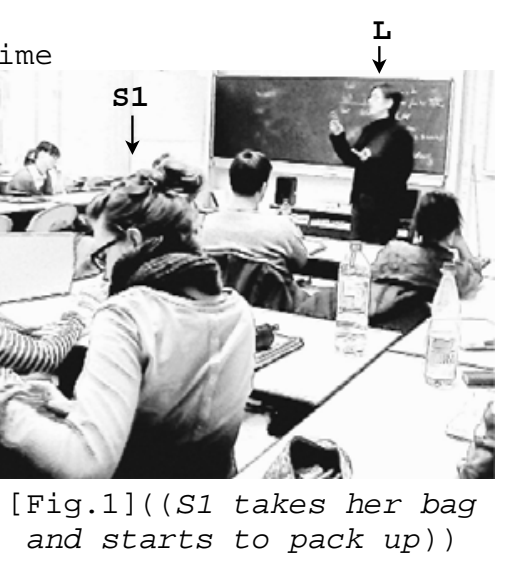

better for fodder and

the:: $u: h$ the the (.)

wood of trees

better for furniture or building material. (.) And regarding animal waste and carcass: there you have already felt in your own reaction or also in the unrest in the room, yuck, yes? It was/people just don't like this. But what happens to pork that is not sold? (.) Animal waste and carcass. [...]

$01: 24: 58$

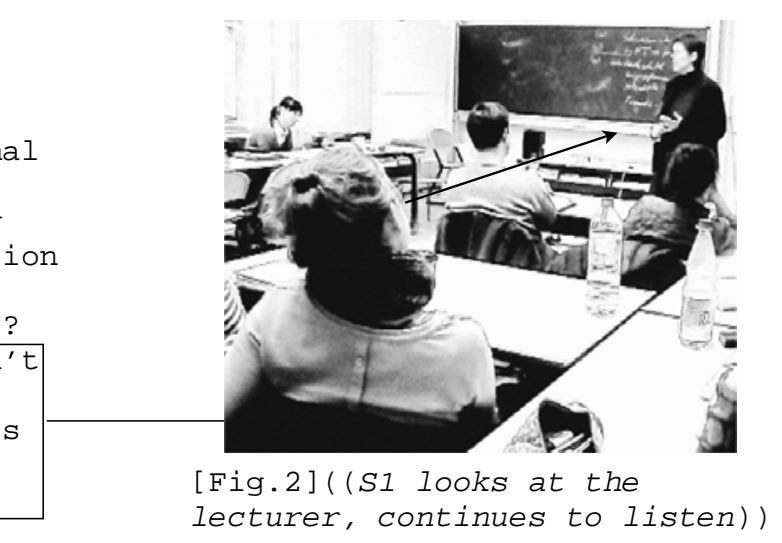


Here, there are about five minutes before the end of the session. The lecturer is currently talking without any indication that she is about to bring her comments, and the seminar session, to a close (lines 1-23). Nevertheless, while the lecturer is talking, one student (S1) slowly starts putting her things away, 'in the middle' of the lecturer's explanations. This is done in a minimally disrupting manner: she takes her bag, which hangs on the back of her chair (Fig. 1), silently puts the pencil case and the notebook in her bag, and then hangs the bag on the back of her chair again, leaving only a bottle of water on her table. Once she has packed up, she again 'visibly’ engages in listening to the lecturer (Fig. 2). 


\section{Fragment 9.2 (continued from Fragment 9.1)}

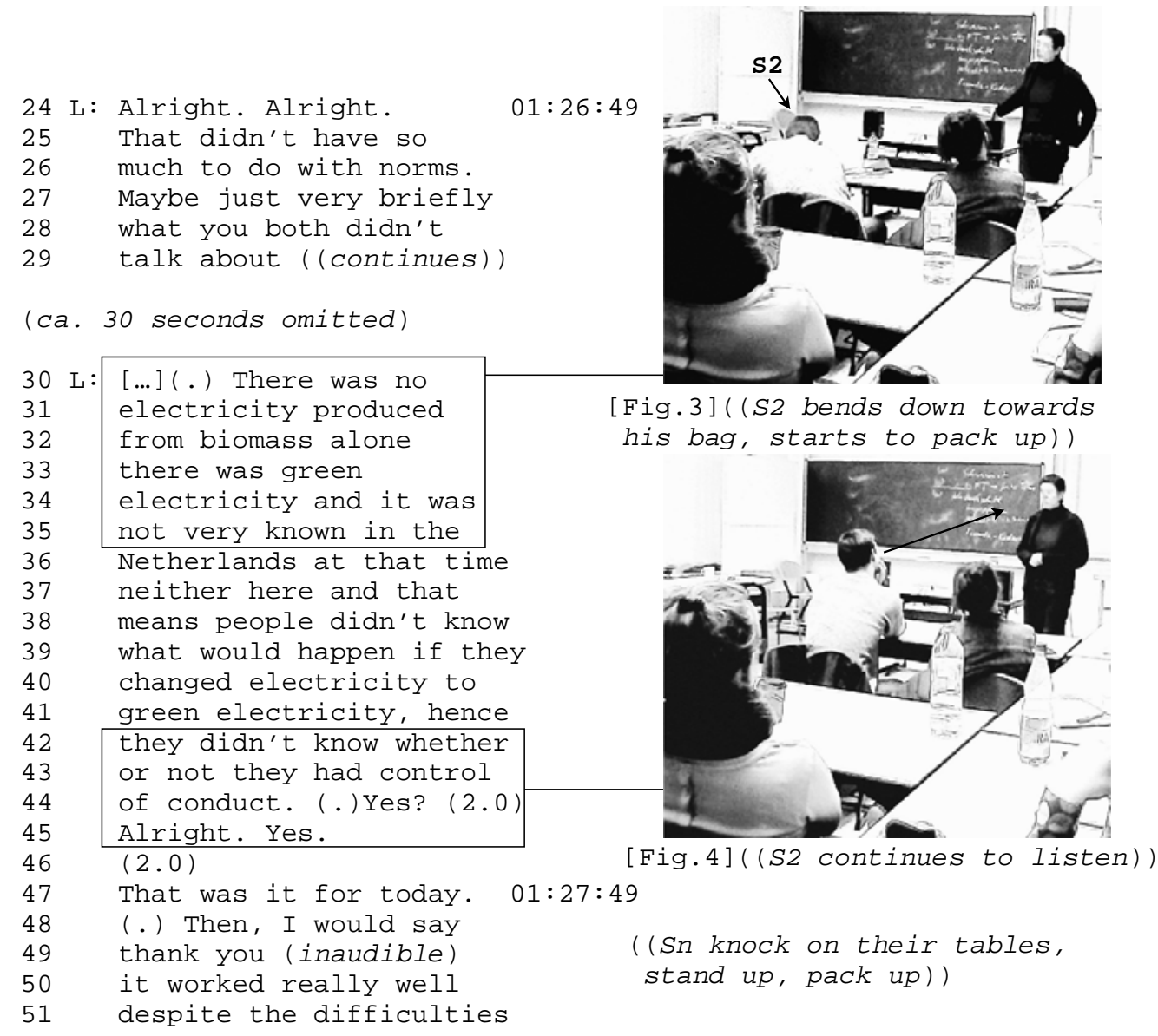

A short while later, another student (S2) also starts putting his things away (Fig. 3), although the lecturer has not yet finished talking. The student starts to pack up after the lecturer introduced a new topic with "Maybe just very briefly" (line 27), which could be heard as an indication that the current point is possibly the last one, i.e. the one before closing the session. What is noticeably is the manner in which S2 packs up: he puts some things in his bag first, listens to the lecturer for a few seconds, continues to pack up, and then listens again (Fig. 4). Both students are trying to pack up slowly and silently. This provides a nice contrast to Fragment 6 where the students' packing up was done noisily (and therefore reprimanded by the lecturer). Here, the students not only show their orientation to the soon expected closing of the session, but also actively try to preserve the classroom order (by staying silent and visibly still listening). 
Such packing up can occur not only close to the end of the scheduled time, but also much earlier. This happens more often in seminars (rather than lectures), which typically have certain phases one has to go through. Thus, in the next fragment, two students start to 'gear up' to leave halfway through a 90 -minute seminar, i.e., with fifty minutes before the official end of the seminar. In order to account for this, it is important to note that this seminar followed the same structure throughout many sessions: the lecturer would open the session and introduce the current topic; after that, student(s) would give a presentation, which would be followed by other students questioning the presenter(s) and feedback to the presenter(s) by both students and lecturer; at the end, the lecturer would close the seminar session. The fragment includes the lecturer's feedback to the presenting student (lines 1-31) and then the lecturer's closing turns (lines 32-40). 


\section{Fragment 10}

ca.52 minutes before the scheduled end time

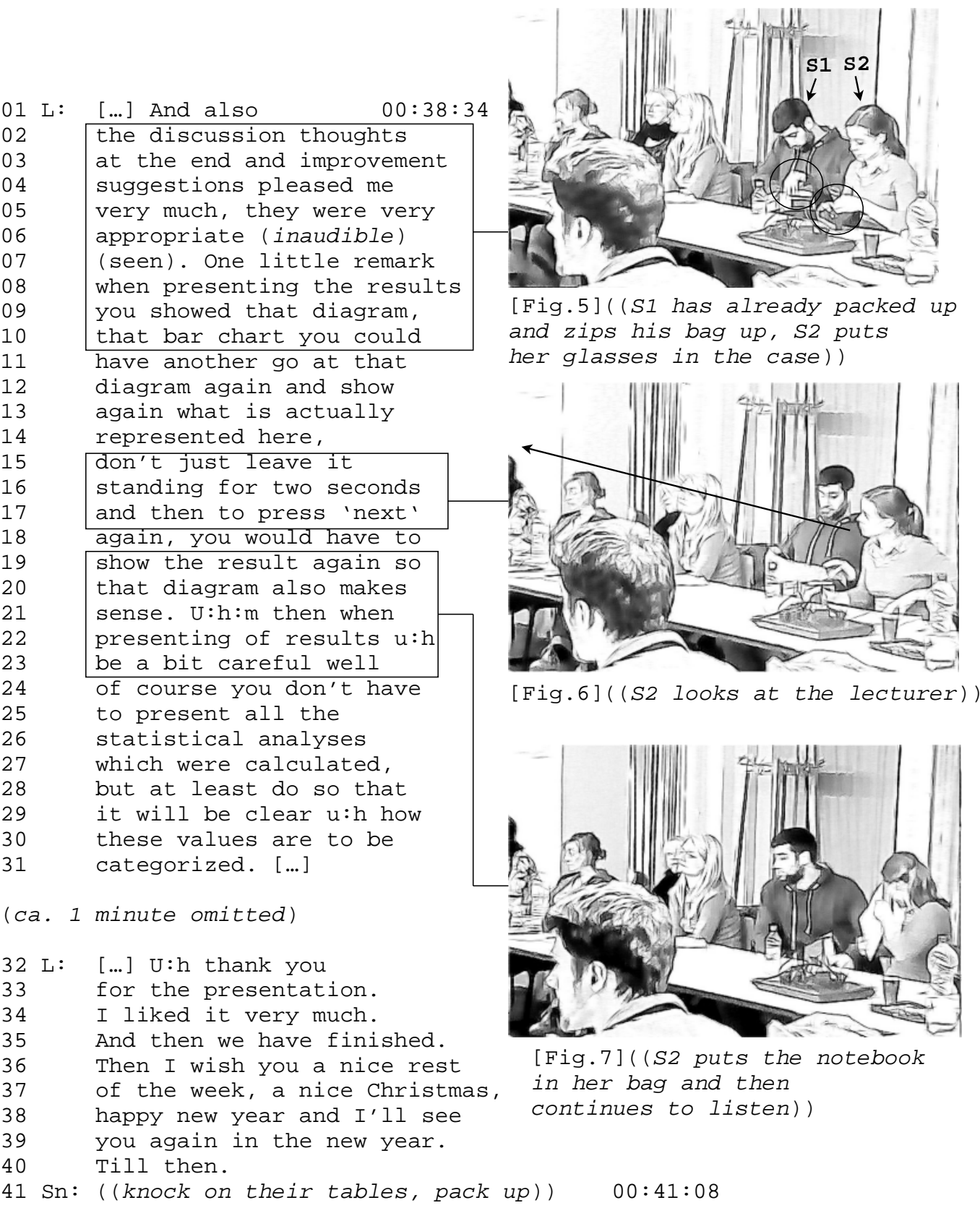

Although this scene occurs 'in the middle' of the session (according to the scheduled 90 minutes), two students start to pack up before the lecturer explicitly announced the closing of the session (Fig. 5). The students here are clearly not oriented to the official end time of the session as in Fragment 9, but rather to the phases of the seminar (as in Fragment 5 above). That is, they are orienting to the fact that the lecturer is currently providing feedback, which 
in previous sessions has been the final phase of the seminar leading up to its closing. And their analysis proves 'correct': the lecturer closes the seminar only two minutes after the students starting to pack up. ${ }^{2}$

Again, it is noticeably how the packing up is accomplished: slowly and quietly, while still demonstrably 'listening' (as was the case in Fragment 9). In other words, the students indicate their readiness to leave while simultaneously preserving the classroom order. They are not just 'packing up', but also making sure that they are (or at least can be seen to be) 'looking at and listening to the lecturer'. For example, after student S2 puts her glasses in the case (Fig. 5), she looks ‘attentively’ at the lecturer (Fig. 6), before putting her notebook in her bag (Fig. 7). So the student is really doing two things at the same time: 'packing up' and 'listening' and, in that sense, she is not disturbing the classroom order: the lecturer can continue her comments without interruption: neither verbally (for instance through pauses) nor nonverbally (through eye contact and body direction) does the lecturer indicate that she is disturbed.

That is not to say, that such (quiet) 'gearing up' is not noticed by the lecturer. However, if done in this manner, the lecturer can choose to ignore this (as in Fragments 8 and 9). Nevertheless, in a certain sense, 'gearing up' to leave prior to an 'official' closing by the lecturer, can be seen as an attempt by students to initiate, or at least to indicate, a closing (which is why packing up may be explicitly sanctioned by lecturers as in Fragments 6 and 7).

\section{Initiating closings}

Although only the lecturer can formally announce the end of the session, the students are typically not simply passive, 'waiting' for the lecturer to close the session. We have already seen that students may 'gear up' to leave thereby indicating to the lecturer that the session is almost over (while still doing so in a way to 'allow' the lecturer to finish what he or she has to say). 
However, students can also be more 'devious' and engage in actions that challenge the classroom order, trying to 'force' the lecturer to end the session quickly, even prior to the scheduled end time. In the following we focus on three practices: 'premature' knocking, producing a 'noisy assemblage', and refusing to participate.

'Premature' knocking. Students' knocking on their tables typically occurs at German universities after the lecturer, towards the scheduled end time, has announced that a seminar session is over (Fragment 2, line 7). However, students can knock at other points as well, thereby treating the previous utterance of the lecturer as an announcement. The following fragment occurs about ten minutes before the scheduled end time of the session. 


\section{Fragment 11}

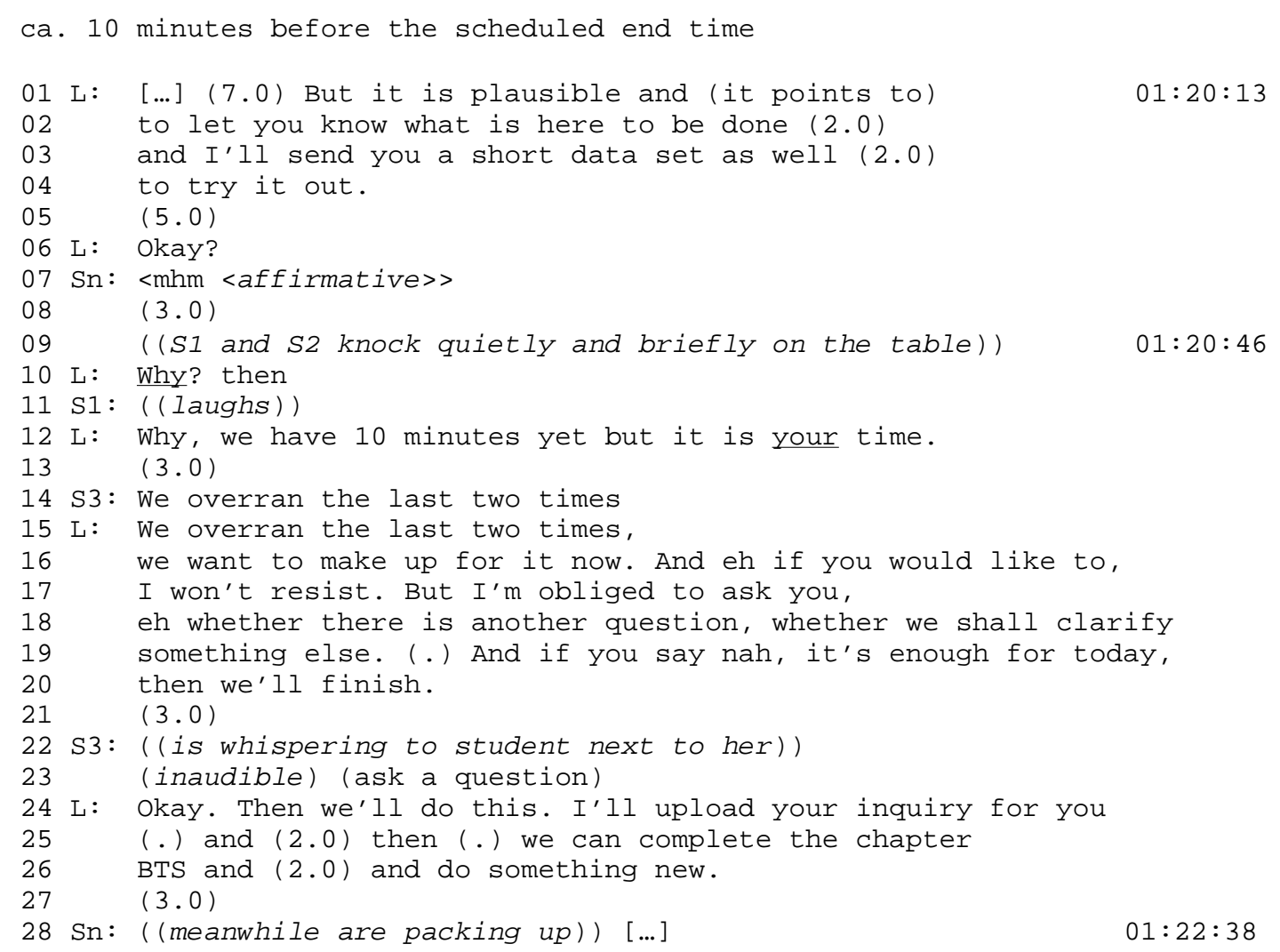

The lecturer announces that he will send the students a data set (lines 3-4), which fails to get any reaction (line 5). Pursuing a response, the lecturer asks “Okay?” (line 6) which now does solicit an affirmative reaction from some students (line 7). After a three second pause, two students knock on the table (line 9). The lecturer responds to this by asking “Why?” (line 10), which prompts the students to laugh (line 11), and the lecturer to state that there are still ten minutes left (line 12).

We would argue that the knocking of the two students (in line 9) is an attempt to initiate a closing, but a closing that would occur ten minutes before the 'official' end. By considering how this attempt is made, we can notice that the knocking is produced and understood (by the lecturer, as well as by the students) as a 'displaced' action (cf. Schegloff and Sacks, 1973: 319-320). For the lecturer, what has been brought to a close (in line 6) is a bit of topic-related talk, but not the session. Consequently, the following knocking of the two students is heard as 
an 'event-in-the-seminar' rather than marking its boundaries (cf. Schegloff and Sacks, 1973: 295), and it is commented on by the lecturer through the explicit reference to 'clock time' (line 12). Compare Fragment 11 with the following:

\section{Fragment 12}

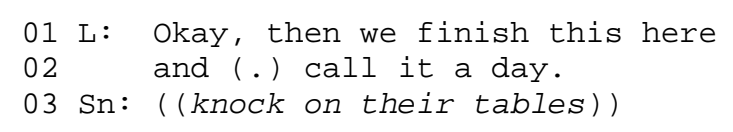

In Fragment 12, the knocking by the students directly follows, and thereby responds to, the lecturer's verbal utterance which marks the closing the session. Furthermore, the knocking is produced by many students. In contrast, in Fragment 11 the knocking occurs after a three second pause (line 8), rather than directly in response to a lecturer's utterance and is only done by two students.

The lecturer's “okay” (line 6) in Fragment 11 could be potentially heard as a 'pre-closing' and the two students use the ambivalence of this formal marker by treating the lecturer's "okay" as a pre-closing (cf. with Fragment 7). Note further that the knocking is done silently, almost hesitantly, indicating students' awareness of the fact that there are still ten minutes 'left'. In other words, the students indicate that they are not sure whether they can initiate a closing at this point. Furthermore, one of two knocking students laughs after the lecturer's reaction to their knocking (line 11). Thus, the students show that they are themselves aware that their knocking can be treated as inappropriate.

The lecturer topicalizes the knocking by asking "Why?" (line 10) and then states that "we have 10 minutes yet but it is your time” (line 12). The students are able to produce an account for their knocking, which trades not so much on this session, but on the previous sessions, namely the fact that the two preceding sessions “overran” (line 14).

Firstly, the fragment exhibits the authority of the lecturer: although students may 'suggest' that it is time to close the session, it is the lecturer's right to do so. The lecturer therefore can 
ask students for an account why they have initiated a closing. Secondly, it points to an orientation of students to seminar time, where students are keeping something like a 'balance sheet': they “overran” in the previous two seminars (line 14), so if they finish early this time, they are back to a zero balance. Thirdly, the whole exchange points to different orientations of lecturer (towards content) and students (towards time), as already hinted at in Fragment 4. If the lecturer 'needs' more time he may bargain with students for 'more' time in order to 'get through' the content (cf. Fragment 4 where the lecturer asks students whether it is 'okay' to go a couple of minutes over).

This fragment not only shows the active role of students in closings, but also points to their occasional ‘devious’ role, where students may treat a lecturer’s utterance (here, “Okay?” in line 7) as if it is initiating a closing. A phenomenon that may be familiar to readers in the context of research talks: Towards the end of a talk, when the speaker has not yet finished, but perhaps has reached the allocated time limit - or the exceeded the patience of the audience the audience can deliberately misinterpret a particular utterance of the speaker (such as "okay") and start clapping, thereby effectively ending the talk even though the speaker may have intended to go on for a little while longer (cf. also Monzoni \& Drew, 2009: 202 on deliberately 'mis-treating' an utterance during a story-telling).

Producing a 'noisy assemblage'. As mentioned above, students' activities towards the end of a session such as 'gearing up' to leave are often noticed by the lecturer who, as we have already seen, can simply ignore this (see Fragments 9 and 10) or react to it by reprimanding the students (see Fragments 6 and 7). Students' 'gearing up' can also lead to the lecturer 'speeding' up, in order to bring the session to a close more quickly. This is the case in the following fragment, which is taken from a seminar in which the lecturer often didn't finish on time. As a result, students often started to pack up just around the scheduled end time, thereby 'forcing' the lecturer to finish the session. In contrast to silent forms of 'gearing 
up' considered above, we here deal with what Garfinkel (2002: 241) has described as the emergence of a "noisy assemblage”. A situation where we are not dealing with a few students packing up silently while continuing to listen, but many students noisily, and visibly, packing up, possibly even standing up (either to put on their jackets or to leave the room). 


\section{Fragment 13.1}

ca. 3 minutes before the scheduled end time

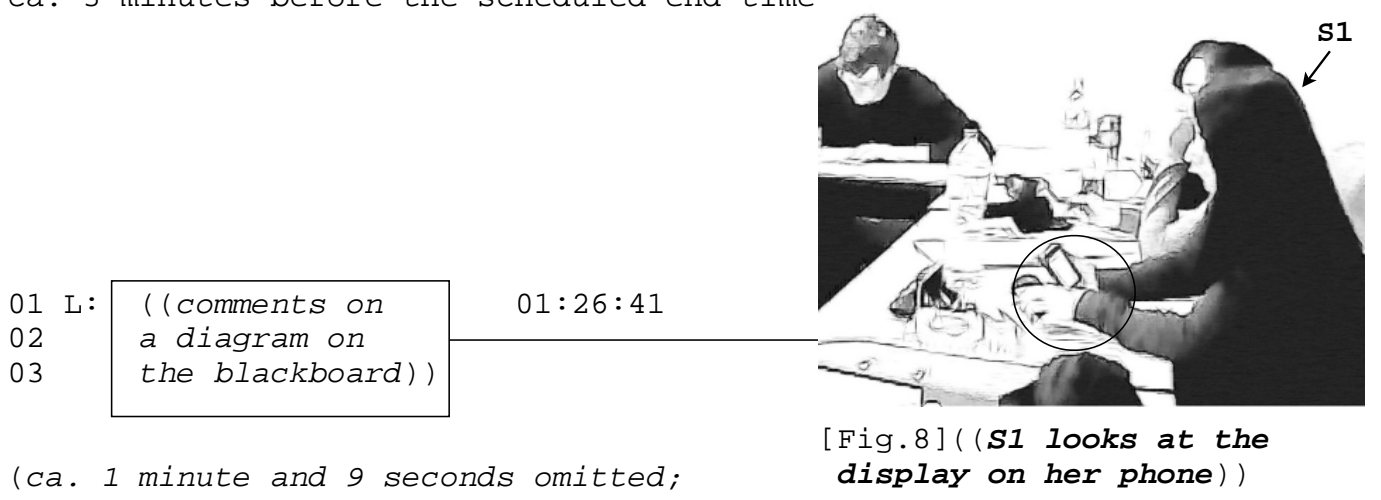
about one and half minutes until the end)

\begin{tabular}{|c|c|}
\hline $04 \mathrm{~L}:$ & ((continues to \\
\hline 5 & comment on a diagram, \\
\hline$\odot$ & makes short pauses \\
\hline 07 & from time to time, \\
\hline & looks at the students \\
\hline & and continues to \\
\hline$\odot$ & comment)) \\
\hline
\end{tabular}

(ca. 1 minute and 32 seconds omitted; about thirty seconds until the end)

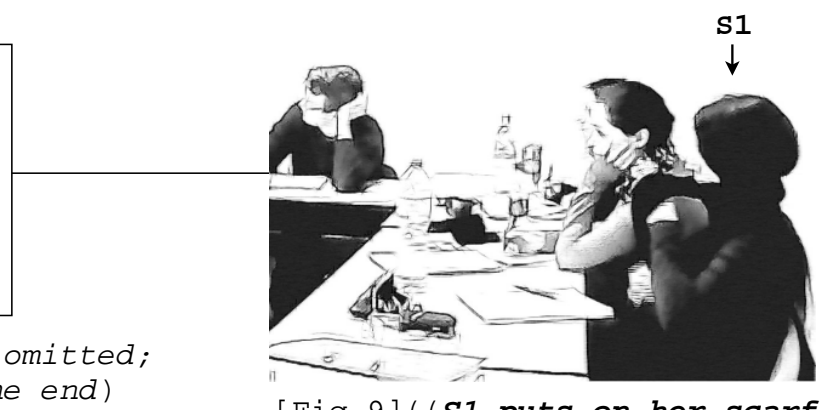

[Fig.9]((S1 puts on her scarf, continues to listen, makes notes))

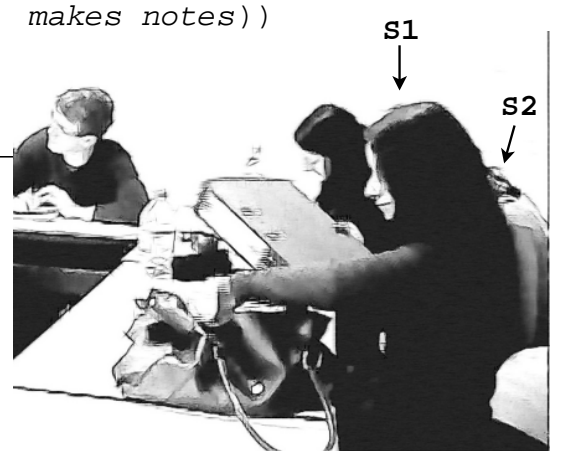

[Fig.10]((S1 and S2 start to pack up, then S1 chats quietly with a student sitting next to s2))

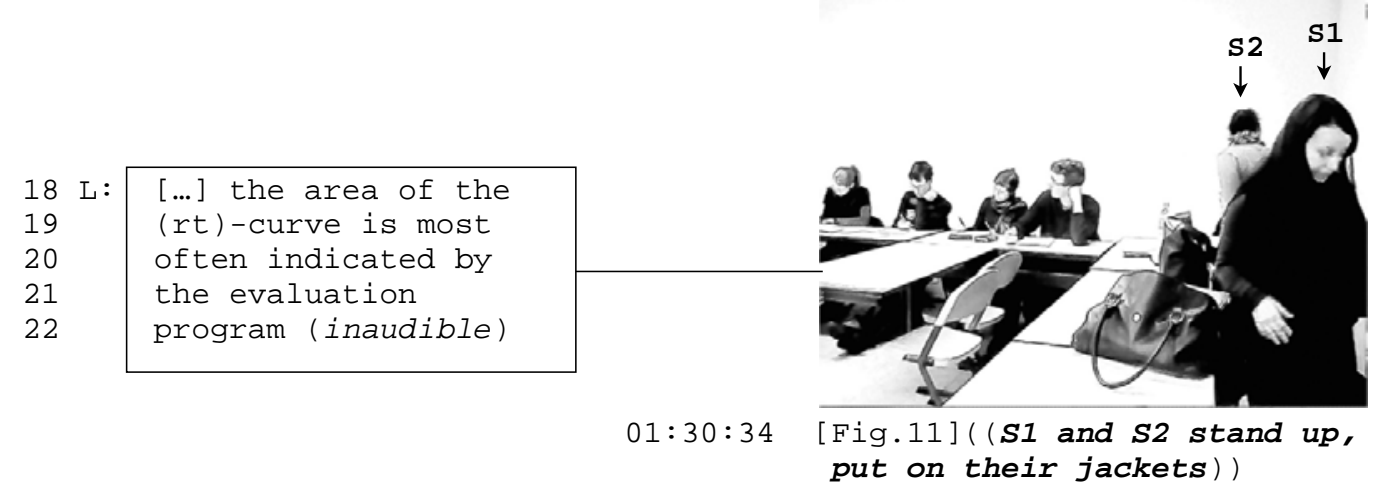

In Fragment 4 above, the lecturer, toward the scheduled end time, had made an explicit acknowledgement that he was aware that the official end time was approaching, altering 
students to the possibility of going over the scheduled end time. In contrast, in this fragment the lecturer in no way demonstrates that he is aware that the scheduled end time is approaching. So three minutes before the scheduled end time, while the lecturer is still talking, one of the student (S1) glances at her phone (Fig. 8), possibly checking the time, and then starts to put on her scarf (Fig. 9). A minute later, both S1 and S2 start to pack up (Fig. 10), before actually standing up (Fig. 11) in order to put on their jackets. Note that standing up is a much more visible move in the seminar room than just putting away your notes into your bag (compare with Fig. 1 in Fragment 9).

In contrast to Fragment 9, the students here are also not demonstrably continuing to listen during, and after, their packing up, but instead are quietly talking to each other (Fig. 10). Thus, the way in which students are gearing up to leave is not done in a manner that attempts to preserve the classroom order, which quickly starts to unravel even further: 


\section{Fragment 13.2 (continued from Fragment 13.1)}

36 seconds after the scheduled end time

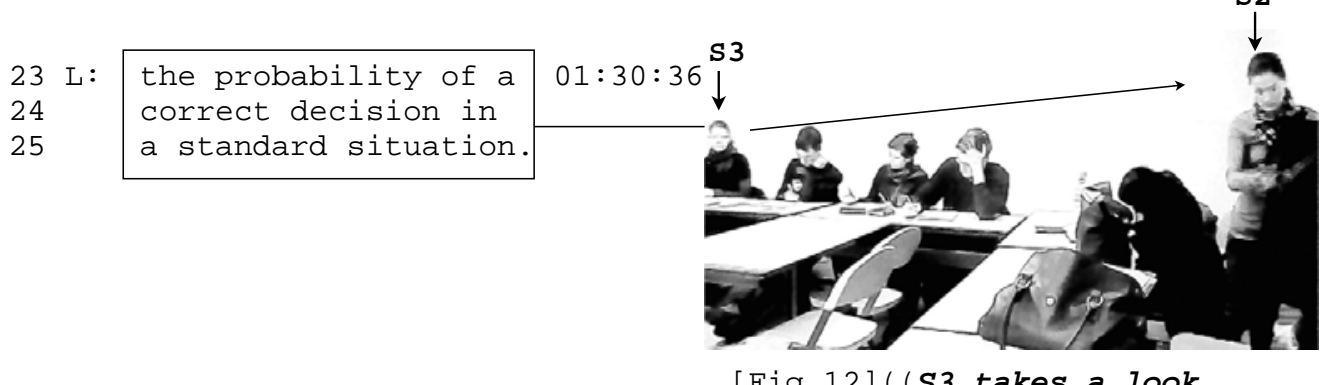

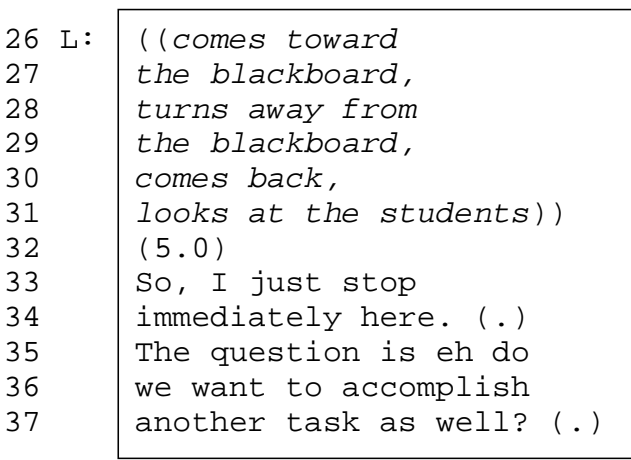

[Fig.12] ( (S3 takes a look at $\mathrm{S1}$ and $\mathrm{S2})$ turns away from blackboard, es back $(5.0)$

So, I just stop

immediately here. (.) another task as well? (.)

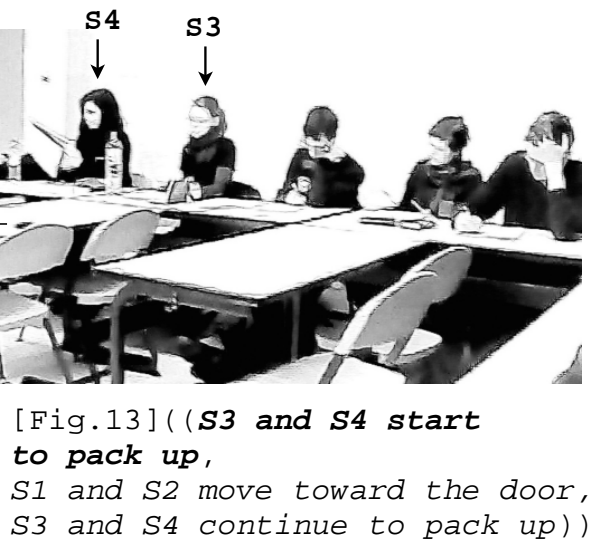

\begin{tabular}{ll|l|}
38 Sn: & Next week \\
39 & $\mathrm{~L}:$ & I offer you/ \\
49 & I just offer you eh \\
41 & a data set eh to \\
42 & calculate we'll see \\
43 & what we get eh it's \\
44 & most often very \\
45 & helpful $(2 . \odot)$ \\
\hline
\end{tabular}

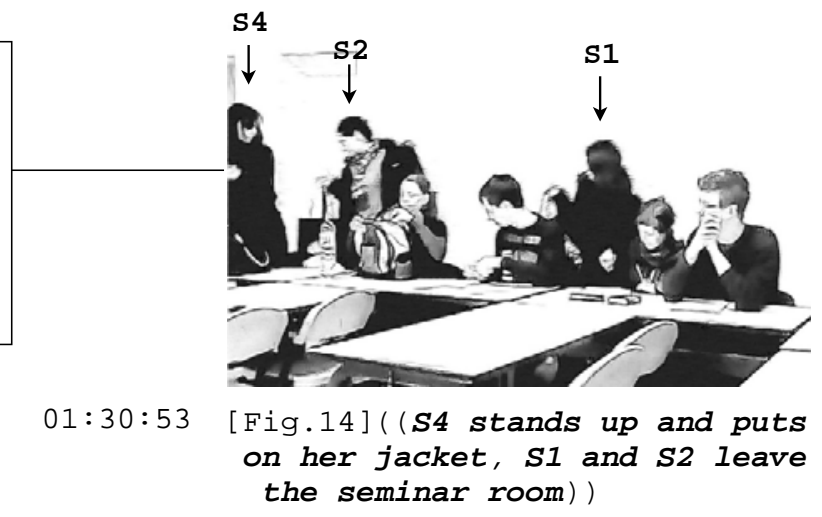

46 L: If you don't get it

47 because of other things

48 to do then (.) that's just

49 that (.) but I upload

the task (inaudible)

and (.) we'll look next

time at how it is with

$\begin{array}{ll}53 & \text { the (inaudible) value } \\ 54 \mathrm{Sn}:((\text { knock on their tables })) & 01: 31: 22\end{array}$

(about one and a half minutes 'over' time)

While the lecturer is continuing to comment on a diagram on the blackboard (lines 23-25),

two students (S1 and S2) have stood up and put on their jackets (Fig. 12, only S2 is visible). 
This is seen by other students and leads to a kind of 'ripple effect'. We can see how S3 takes a look at S2 (Fig. 12) and immediately after that, S3 and S4 also close their notebooks and start to pack up (Fig. 13). At this point, the lecturer finally moves into closing (“So, I just stop immediately here”, line 14) and a few moments later, just at the point of the scheduled end time, S1 and S2 starts to move towards the door and leave the room (Fig. 14).

This fragment builds a nice contrast to Fragment 9, where students also pack up, but do so in a way that does not disrupt the classroom order. In contrast, in this fragment the packing up by students is done in a way that increasingly disintegrates the classroom order. Indeed, the final utterances of the lecturer (lines 39-53) are done when the order has almost disappeared: the room is gradually being filled with the sound of zipping bags, whispering, snapping files, closing books and putting them in bags.

Note that the students are here packing up not during the lecturer's closing (as in Fragment 3), but do it in parallel to the lecturer's topical talk. Of course, they do not do so 'anywhere', but towards, and after, the end of the scheduled end time. As Garfinkel (2002: 242) pointed out, as the end of the session approaches, "the clock comes into prominent relevance as does [...] audience restiveness, [and] the lecturer's orientation to their restiveness”. On the videotape we can see the lecturer's orientation to the restiveness of the students (Fragment 13.2.1): 
Fragment 13.2.1 (detail of Fragment 13.2, lines 26-34)

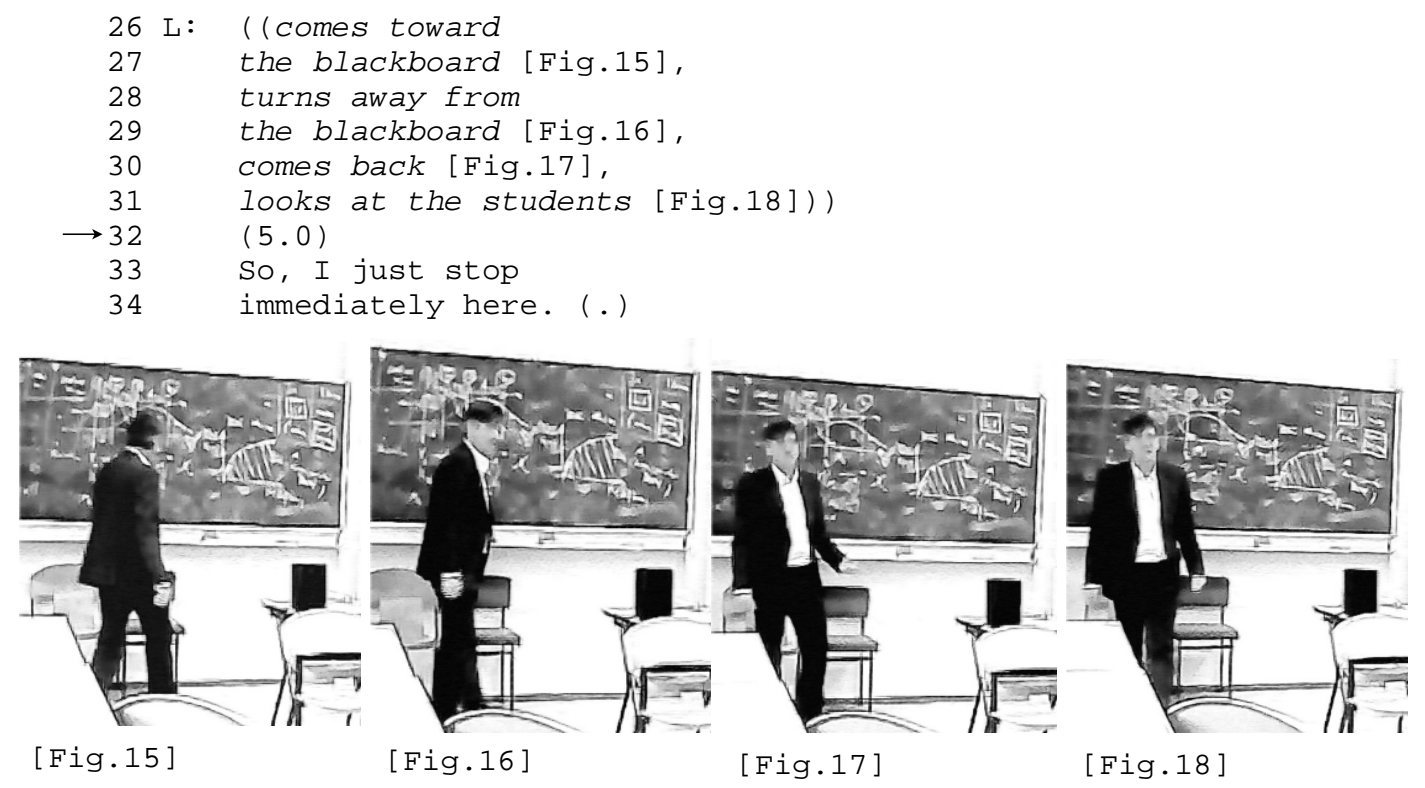

The lecturer moves towards the blackboard, probably to write one new formula or to point at a diagram (Fig. 15), but then abandons his move (Fig. 16), comes back (Fig. 17), faces the audience (Fig. 18), before uttering: “So, I just stop immediately here” (lines 31-34).

In this instance, it could be said that it is the students, through their packing up and actually leaving the room, who initiate the closing. However, the students' actions - including to stand up to put on their jackets - are not reprimanded (in contrast to Fragments 6 and 7), presumably as a result of when this occurs, namely just at the point of the scheduled end time. Neither is it topicalized in any way (as in Fragment 11).

We can see very clearly the active role of students in accomplishing closings. Looking at the lecturer, we see him orienting - and reacting - to what is happening in the seminar room around him. Notice the five second pause (line 32) during which the lecturer abandons his current course of action and publicly notices the packing up the room, but in a way that does not call this into question. Again, we can find different, even competing, orientations here. While the lecturer is obviously oriented to the content of the seminar, intending to continue his explanations, the students show their orientation to 'clock time' by packing up and thereby 
signalling to the lecturer that will be, and in the end is, going over the scheduled end time.

Refusing to participate. In seminars (rather than lecturers) filling the time is often dependent on the contributions of students to the session. When such contributions are not forthcoming, lecturers are faced with the practical problem of what to do. Lecturers have different possibilities to solve that problem. For example, they can wait until the answer comes, they can answer the question themselves, or they can call on a particular student. However, in other cases, students' non-participation can lead to lecturers simply closing the session 'earlier'. Interestingly, this can occur not only towards the end of a seminar, but also 'in the middle' of a session (cf. footnote 2). In the following, we examine two fragments in which the students' actions can be treated as an attempt to refuse to do what the lecturer want them to do, which, in one case, results in an 'earlier' closing of the session.

This seminar was structured as follows: after a short introduction by the lecturer, students would give a presentation (about 20 minutes), after which the lecturer would start a discussion to cover the remaining time (often 40 minutes). This did not always work, especially the discussion phase was sometimes problematic, leading to a situation where it was difficult for the lecturer to generate further talk by the students. The scene in Fragment 14 takes place about five minutes before the scheduled end time. Four students are standing at the blackboard, answering the lecturer's questions regarding their presentation.

\section{Fragment 14}

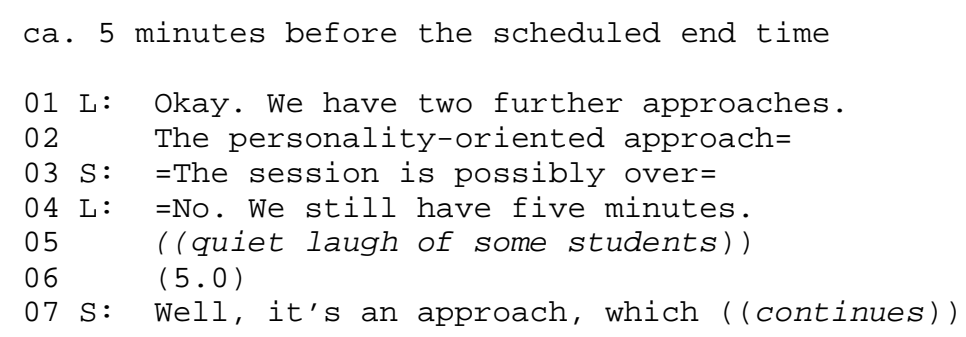


The lecturer's utterance in line 1, "We have two further approaches", can be heard as an attempt to initiate further discussion. After the lecturer names the first of these two approaches (line 2), a student suggests that the "session is possibly over" (line 3). This is challenged by the lecturer, who instead argues that there are still five minutes left (line 4), which prompts some students to laugh (line 5). After a short pause, one of the students continues with the seminar-talk by defining the approach in question (line 7).

The student's utterance in line 3 not simply alerts the lecturer to the remaining time, but actually constitutes an alternative suggestion to that of the lecturer: rather than dealing with "two further approaches", the student proposes that the session should be finished. In other words, it is an attempt by the student to initiate a closing, albeit an attempt that is produced as a suggestion: note that the student says "the session is possibly over" (our emphasis), in a sense, only inviting the lecturer to consider an alternative course of action. Note further the laughter in line 5, which is not a reaction to a humours remark by the lecturer, but more likely a reaction to the student's failed attempt to 'invite' the lecturer to close the session.

Again, we find two divergent orientations: Whereas the lecturer is obviously oriented to the content of the seminar (which would suggest to continue the session), the student seems to be more concerned with clock time (which might suggest to close the session).

There is a similarity between the student's utterance "The session is possibly over" (Fragment 14, line 3) and the 'premature' knocking (Fragment 11, line 9). In both cases, students are not just active in (trying to) initiate a closing, they do so in a slightly 'cheeky' or 'devious' manner (notice that in both instances their attempt is followed by laughter either of the 'initiator' herself or of fellow students). Indeed, the students are actually trying to 'cut off' the length of the session short by making use of the scheduled nature of the seminar. 
In Fragment 15, the participants are in a similar situation: three students are standing at the blackboard, answering the lecturer's questions.

\section{Fragment 15}

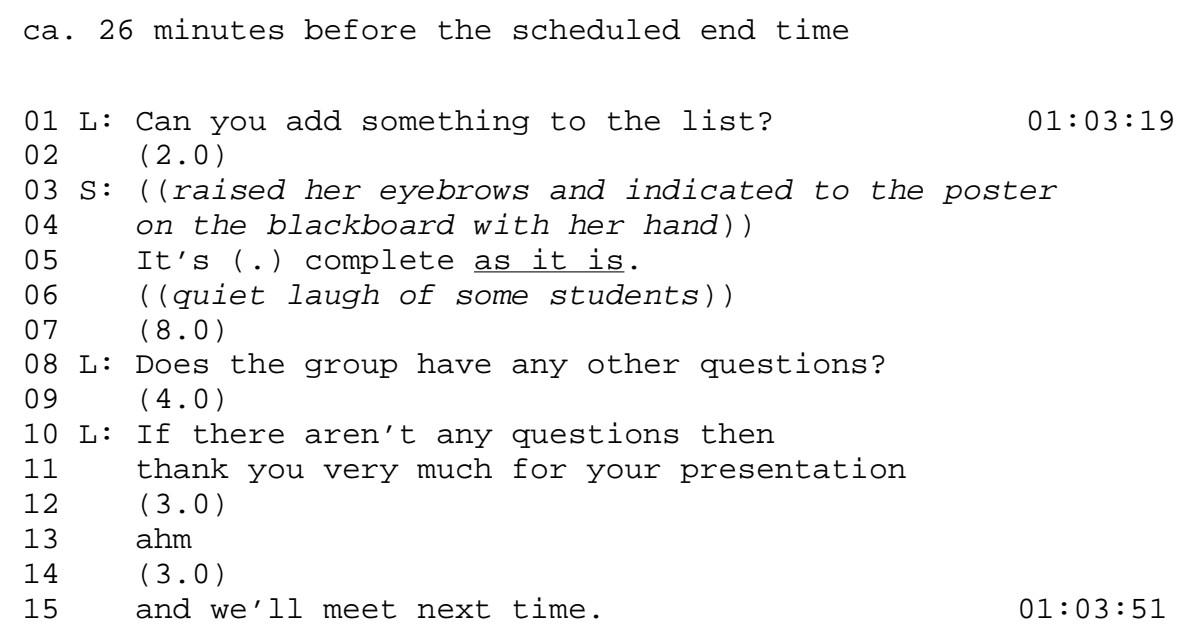

The lecturer asks the students who are standing in front of the blackboard to add to a list they presented earlier (line 1). Instead of doing so, one of the students, verbally as well as paraverbally (through raising of her eyebrows and her emphasis of "as it is"), indicates that the lecturer's request is not to be pursued. Her answer "It's complete as it is" (line 5) does not just provide an alternative characterisation of the list: the lecturer had treated it as incomplete, the student characterises it as 'complete'. By refusing to make further contributions to the discussion, the student rather makes an attempt to initiate a closing of this phase of the seminar (and thereby, possibly, even the whole session). Notice further how the student's utterance is followed by laughter by some students (as in Fragment 14, line 5; Fragment 11, line 11). This laughter can be heard as a reaction to the student's attempt to 'cut off' the lecturer's request.

After a long silence (line 7), the lecturer abandons this course of action (asking the presenters to produce further talk) and instead turns to the non-presenters, asking whether they have further questions (line 8). None are forthcoming, which leads the lecturer to end the 
'presentation' phase of the session (lines 11), before closing the session (line 15), 25 minutes before the scheduled end time.

The last two fragments clearly show the active role that students play in the accomplishment of university seminars, and the resources they have to initiate a closing. In Fragment 14, a student suggests that "the session is possibly over" (line 3), while in Fragment 15, a student argues that a list is "complete as it is" (line 5). Both are attempts to initiate a closing. Interestingly, it is the latter (twenty-five minutes before the end) rather than the former (only five minutes before the end) that is successful. In Fragment 14, the student only produced an alternative suggestion (let's not deal with these, but finish the session now), whereas in Fragment 15, the students simply refuse to produce further topic-related talk, without using the remaining time as a reason for this (which, in fact, would be difficult, because there are still 25 minutes left).

While students may attempt to initiate closings during lectures, especially if it looks like the lecturer is going 'over time', it is perhaps during seminars that the active, even devious role, of students becomes most visible, for the simple reason that the lecturer is more dependent on them. For a lecture, the students only need to continue to listen (i.e., stay quiet, look at the lecturer, etc.), while the lecturer continues to talk. In contrast, seminars are typically constructed in a way that builds on the contributions of students. Once these are no longer forthcoming, the lecturer can either turn the seminar into a lecture, or has to finish the session earlier.

\section{Conclusion}

In this paper, we have shown that the end of lectures and seminars does not just happen, but has to be accomplished. Just as classroom lessons do not simply begin with the ringing of the bell (though the bell is a critical resource for accomplishing the beginning), so university 
seminars and lectures do not simply end at the officially scheduled time, but have to be brought to a close through the collaborative work of lecturers and students. It is the lecturer who has the right to close a lesson (as does the teacher in the school context, cf. Payne, 1979: 269; Hustler and Payne, 1982: 56; Manke, 1997: 63-64) and frequently it is the lecturer who does initiate the closing of a session. However, as we have shown, students also play an active role in the accomplishment of closings, since they may not simply follow the lecturer's initiation by packing up or knocking on the table, but also initiate the closing.

Thus, this paper has made a contribution to the recent shift away from a teacher-centred analytical perspective to one that emphasizes the active role that students play in the organization of classroom order and interaction (Macbeth, 1990; Manke, 1997). While most previous studies have investigated students' verbal contributions to classroom discourse (Jacknick, 2009; Waring, 2011), we have pointed to the various resources that participants have to accomplish this. In particular, we have shown how both lecturer and students take account of the remaining time of the session, i.e., of clock time and of session phases. This is particularly pertinent in seminars (rather than lectures) which are more dependent on the contribution of students. We have also exhibited the nonverbal practices of students in achieving closings (cf. Broth and Mondada, 2013). Through such activities as packing up or wearing jackets students can 'instruct' the lecturer to move into closing and thereby to finish the session on time or even earlier.

As we have shown, students do not just wait for the lecturer to close the session, but can do very actions prior to this. They can do so in ways that demonstrably attempt not to disrupt the classroom order, e.g., by packing up quietly, followed by demonstrably 'doing listening' to show that they are still engaged in the session (Fragments 9 and 10). Alternatively, students may engage in such activities that do disrupt the classroom order, e.g., by noisily packing up or starting to chat to their neighbour (Fragment 13) and thereby producing the all-to-familiar 
'noisy assemblage’ (Garfinkel, 2002: 241). Lecturers, in turn, may try to forestall students 'gearing up' towards the end of the session (Fragments 6, 7 and 8).

Students are thus not just contributing to the accomplishment of closings by simply reacting to the lecturer's closing activities, they may also try to initiate closings. For example, they may engage in 'premature knocking' (Fragment 11), they may pack up and start to leave the room, even while the lecturer is still talking (Fragment 13), they may verbally suggest that the session is over (Fragment 14), or even refuse to participate in the session (Fragment 15). Such attempts, while in a certain sense 'subversive', often still re-affirm the authority of the lecturer: they are done hesitantly (e.g., the knocking in Fragment 11, line 9) or formulated as a suggestion (“The session is possibly over”, Fragment 14, line 3; our emphasis). Furthermore, the 'subversive' nature of these actions is in no way hidden, but visible to everyone in the room. When the lecturer topicalizes these actions, there is often laughter from fellow students, demonstrating that everyone is fully aware of what is going on.

While we think it would be too strong to speak of any 'conflict' between lecturers and students, we do think that these fragments point to an occasional difference in orientations between them. Students are often primarily oriented to clock time (and typically do not mind finishing early), while the lecturer is often oriented to the subject matter and content (and may be willing to run over in order to finish a particular point - see Fragments 4 and 5). The difference becomes particularly visible when approaching the end of the scheduled time. If the lecturer is going over the scheduled end time - or can be seen to be heading that way students may become more and more active in the ways that they attempt to bring the session to a close. Students do not just passively monitor the time, but may occasionally 'remind' the lecturer takes into account their right 'to be let out on time'. In rare cases, they may even make 'subversive' attempts to shorten the length of a session. 


\section{Notes}

1. For school lessons phases, see Mehan (1979: 36) and Hargreaves et al. (1975: 67).

2. The constitutive role of seminar phases is also confirmed by the lecturer herself. To the question "Why was the session closed so early?", she replied with the following reason: "Because there was not a discussion. I think it's silly to keep them [the students] artificially here".

\section{References}

Apple, M. W. (1995) Education and Power. London: Routledge.

Bernstein, B. (1975) Class, Codes, and Control (Vol. 3). London: Routledge \& Paul Kegan.

Bourdieu, P., and Passeron, J.-C. (1990 [1977]) Reproduction in Education, Society and Culture. Translated by Richard Nice. London: Sage.

Breidenstein, G. (2006) Teilnahme am Unterricht. Ethnographische Studien zum Schülerjob. Wiesbaden: Springer.

Broth, M., and Mondada, L. (2013) Walking away: The embodied achievement of activity closings in mobile interaction. Journal of Pragmatics, 47(1), 41-58.

Candela, A. (1999) Students' power in classroom discourse. Linguistics and Education, 10(2), 139-163.

Clayman, S. (1989) The production of punctuality: Social interaction, temporal organization, and social structure. American Journal of Sociology, 95(3), 659-691.

Clayman, S., and Heritage, J. (2002) The News Interview: Journalists and Public Figures on the Air. Cambridge: Cambridge University Press.

Cooper, I. (1982) The maintenance of order and use of space in primary school buildings. British Journal of Sociology of Education, 3(3), 267-279. 
Francis, D. and Hester, S. (2004) An Invitation to Ethnomethodology. London: Sage.

Garfinkel, H. (1967) Studies in Ethnomethodology. Englewood Cliffs, NJ: Prentice-Hall.

Garfinkel, H. (2002) Ethnomethodology's Program: Working Out Durkheim's Aphorism. Lanham: Rowman \& Littlefield.

Garton, S. (2012) Speaking out of turn? Taking the initiative in teacher-fronted classroom interaction. Classroom Discourse, 3(1), 29-45.

Giddens, A. (1984) The Constitution of Society. Cambridge: Polity Press.

Greiffenhagen, C. (2008) Unpacking tasks: The fusion of new technology with instructional work. Journal of Computer Supported Cooperative Work (JCSCW), 17(1), 35-62.

Greiffenhagen, C. (2014) The materiality of mathematics: Presenting mathematics at the blackboard. British Journal of Sociology, 65(3), 502-528.

Hargreaves, D. H., Hester, S., and Mellor, F. J. (1975) Deviance in Classrooms. London: Routledge \& Kegan Paul.

Heath, C. (1985) The consultation's end: The coordination of speech and body movement. International Journal of the Sociology of Language, 51, 27-42.

Hecht, M. (2013) Unterricht auf der Kippe - Über das Ausbalancieren von Aufmerksamkeit und disziplinierter Subjektivität. In R. Hörster, S. Köngeter, and B. Müller (Eds.) Grenzobjekte. Soziale Welten und ihre Übergänge. Wiesbaden: Springer, pp. 163-183.

Hustler, D. E., and Payne, G. (1982) Power in the classroom. Research in Education, 28, 4964.

Ivarsson, J., and Greiffenhagen, C. (2015) The organization of turn-taking in pool skate sessions. Research on Language and Social Interaction, 48(4), 406-429.

Jacknick, C. (2009) A conversation analytic account of student-initiated participation in an ESL classroom. Unpublished doctoral dissertation, Columbia University, USA.

Jackson, P. W. (1968) Life in Classrooms. New York: Holt, Rinehart \& Winston. 
Jefferson, G. (1984) Notes on some orderlinesses of overlap onset. In V. D’Urso, and P. Leonardi (Eds.) Discoure analysis and natural rhetoric. Padua, Italy: Cleup Editore, pp. 11-38.

Kääntä, L. (2014) From noticing to initiating correction: Students' epistemic displays in instructional interaction. Journal of Pragmatics, 66, 86-105.

Koole, T., and Elbers, E. (2014) Responsiveness in teacher explanations: A conversation analytical perspective on scaffolding. Linguistics and Education, 26, 57-69.

Koutrouba, K., Baxevanou, E., and Koutroumpas, A. (2012) High school students' Perceptions of and attitudes towards teacher power in the classroom. International Education Studies, 5(5), 185-198.

LeBaron, C. D., and Jones, S. E. (2002) Closing up closings: Showing the relevance of the social and material surround to the completion of interaction. Journal of Communication, 52(3), 542-565.

Lindwall, O., and Lymer, G. (2008) The dark matter of lab work: illuminating the negation of disciplined perception in mechanics. Journal of the Learning Sciences 17 (2), 180-224.

Luke, A. (1995-1996) Text and discourse in education: An introduction to critical discourse analysis. Review of Research in Education, 21, 3-48.

Macbeth, D. H. (1987) Managements’ Work: The Social Organization of Order and Troubles in Secondary Classrooms. Ph. D. thesis, University of California, Berkeley.

Macbeth, D. H. (1990) Classroom order as practical action: The making and un-making of a quiet reproach. British Journal of Sociology of Education, 11 (2), 189-214.

Macbeth, D. H. (1991) Teacher authority as practical action. Linguistics and Education, 3(4), 281-313.

Macbeth, D. H. (1992) Classroom 'floors': Material organizations as a course of affairs. Qualitative Sociology, 15(2), 123-150. 
Macbeth, D. H. (2003) Hugh Mehan’s Learning Lessons reconsidered: On the differences between the naturalistic and critical analysis of classroom discourse. American Educational Research Journal, 40(1), 239-280.

Manke, M. P. (1997) Classroom Power Relations: Understanding Student-Teacher Interaction. Mahwah, NJ: Lawrence Erlbaum.

Margutti, P. (2011) Teachers' reproaches and managing discipline in the classroom: When teachers tell students what they do 'wrong'. Linguistics and Education 22(4), 310-329.

Margutti, P., and Drew, P. (2014) Positive evaluation of student answers in classroom instruction. Language and Education, 28(5), 436-458.

McHoul, A. (1978) The organization of turns at formal talk in the classroom. Language in Society, 7, 183-213.

McNeil, L. M. (1982) Contradictions of Control: The Organizational Context of School Knowledge. Madison: Wisconsin Center for Public Policy.

Mehan, H. (1979) Learning Lessons: Social Organization in the Classroom. Cambridge, MA: Harvard University Press.

Monzoni, C. M., and Drew, P. (2009) Inter-interactional contexts of story-interventions by non-knowledgeable story recipients in (Italian) multi-person interaction. Journal of Pragmatics 41(2): 197-218.

Paoletti, I., and Fele, G. (2004) Order and disorder in the classroom. Pragmatics, 14(1), 6985.

Park, I. (2012) Seeking advice: Epistemic asymmetry and learner autonomy in writing conferences. Journal of Pragmatics, 44, 2004-2021.

Payne, G. C. F. (1976) Making a lesson happen: an ethnomethodological analysis. In M. Hammersley, and P. Woods (Eds.) The Process of Schooling: A Sociological Reader. London: Routledge, pp. 33-40. 
Payne, G. C. F. (1979) Some Aspects of the Social Organisation of Classroom Talk. Ph. D. thesis, Manchester University.

Payne, G. C. F., and Hustler, D. (1980) Teaching the class: The practical management of a cohort. British Journal of Sociology of Education, 1(1), 49-66.

Robinson, J. D. (2001) Closing medical encounters: two physician practices and their implications for the expression of patients' unstated concerns. Social Science \& Medicine, 53(5), 639-656.

Sacks, H. (1992) Lectures on Conversation (Edited by G. Jefferson). Oxford: Blackwell.

Schegloff, E. A. (1996) Confirming allusions: toward an empirical account of action. American Journal of Sociology, 102(1), 161-216.

Schegloff, E. A. (2007) Sequence Organization in Interaction. Cambridge: Cambridge University Press.

Schegloff, E. A., and Sacks, H. (1973) Opening up closings. Semiotica, 8(4), 289-327.

Sinclair, J., and Coulthard, M. (1975) Towards an Analysis of Discourse. The English Used by Teachers and Pupils. London: Oxford University Press.

Turner, R. (1972) Some formal properties of therapy talk. In D. Sudnow (Ed.) Studies in Social Interaction. New York: Free Press, pp. 367-396.

Waring, H. Z. (2011) Learner initiatives and learning opportunities in the language classroom. Classroom Discourse, 2(2), 201-218.

West, C. (2006) Coordinating closings in medical interviews: producing continuity of care. In J. Heritage, and D. W. Maynard (Eds.) Communication in Medical Care: Interaction Between Primary Care Physicians and Patients. Cambridge: Cambridge University Press, pp. 379-415.

Young, M. F. D. (1971) Knowledge and Control: New Directions for the Sociology of Education. London: Collier-Macmillan. 


\section{Author biographies}

Tanya Tyagunova, is a research fellow at the Martin Luther University Halle-Wittenberg and University of Kassel, Germany. She completed her PhD in 2016. Her research interests are in ethnomethodology, conversation analysis, ethnography and social interaction in educational settings. One prominent research area is students' interaction management and university assessment practices.

Christian Greiffenhagen, is Assistant Professor in Sociology at the Chinese University of Hong Kong, China and Senior Lecturer at the Department of Social Sciences at Loughborough University, England. With a background in mathematics and computer science, he is concerned with understanding the social dimensions of science and technology. He has conducted a variety of video-based ethnographic studies informed by ethnomethodology (EM) and conversation analysis (CA), investigating, for example, the introduction of educational software into classrooms, the workaday practices of professional mathematicians, or the organization of turn-taking in skateboarding. 